\title{
Wpływ funduszy unijnych \\ na rozwój przedsiębiorczości po akcesji Polski do UE - przegląd wybranych form wsparcia
}

\begin{abstract}
Przemystaw Dubel*
Rozwój mikro- i małej przedsiębiorczości stanowi o sukcesie gospodarczym krajów Unii Europejskiej, dlatego priorytetowo wspierane i dofinansowane sa projekty realizowane przez ten sektor gospodarki. Niewatpliwie możliwość uzyskania dotacji na prowadzenie dziatalności gospodarczej i podwyższenie jej konkurencyjności spowodowała przyrost nowo zakładanych podmiotów gospodarczych.

Wedlug danych na koniec września 2015 r. ok. 31 tys. przedsiębiorstw skorzystało z funduszy unijnych na realizacje projektów inwestycyjnych, dodatkowo wsparcie otrzymato ok. 250 instytucji z otoczenia biznesu. Zrealizowane projekty przyczynity się do rozwoju spoteczno-ekonomicznego, zdynamizowania gospodarki oraz podniesienia atrakcyjności inwestycyjnej naszych regionów na arenie międzynarodowej.

Fundusze unijne z jednej strony staly się jednym $z$ gtównych determinantów zwiększajacych innowacyjność polskiej gospodarki, $z$ drugiej zaś - priorytetowa forma finansowania zewnętrznego będacego głównym elementem tzw. mikrootoczenia przedsiębiorcy. Największym zainteresowaniem cieszyly się programy, z których polskie firmy mogly realizować bezpośrednie inwestycje na odbudowe parku technologicznego oraz podnoszenie kompetencji swoich pracowników.

Celem niniejszego artykułu jest identyfikacja, porównanie i ocena wykorzystania wybranych form wsparcia rozwoju przedsiębiorczości z funduszy UE oraz przedstawienie rezultatu badania ankietowego, które zostato zrealizowane w 2014 roku. Zaprezentowane wyniki potwierdzily wysoka ocenę znaczenia środków unijnych w procesie inwestycyjnym realizowanym przez polskich przedsiębiorców.
\end{abstract}

Słowa kluczowe: polityka regionalna, konkurencyjność, dotacje dla MSP, fundusze UE.

Nadesłany: 10.08.2016 | Zaakceptowany do druku: 08.10.2016

The impact of EU funds on the development of entrepreneurship after Poland's accession to the EU - a review of selected forms of support

The development of micro and small enterprises translates into economic success of the Member States, therefore projects realised by this economic sector receive such strong support and large subsidies. Without doubt the opportunity to obtain subsidies for business activity whose aim was to enhance competitiveness generated the increase of new business entities.

Przemysław Dubel, dr inż. - Wydział Zarządzania Uniwersytetu Warszawskiego.

Adres do korespondencji: Wydział Zarządzania Uniwersytetu Warszawskiego, ul. Szturmowa 1/3, 02-678

Warszawa; e-mail: pdubel@wz.uw.edu.pl. 
According to data published at the end of September 2015, about 31,000 enterprises were subsidised by EU funds in order to execute their investment projects and about 250 business environment institutions were granted subsidies. The projects realised contributed to the social and economic development of regions, revitalisation of the economy and the enhancement of our international competitiveness.

EU funds, on one hand, have become one of the major determinants of increasing the innovation of the Polish economy, on the other a priority form of external financing as a major component of the so-called micro-entrepreneurs. These are manifest in highly popular programs from which Polish companies have been able to realize direct investment in the reconstruction of technology parks along with improving the competence of their employees.

The purpose of this article is to identify, compare and evaluate the use of some forms of enterprise development support from EU funds and present the results of the survey which was completed in 2014. The presented results confirm the high assessment of the importance of EU funds in the investment process implemented by Polish entrepreneurs.

Keywords: regional policy, competitiveness, subsidies for SMEs, EU funds.

Submitted: 10.08.2016 | Accepted: 08.10.2016

JEL: A11

\section{Wstęp}

Od momentu akcesji Polski do Unii Europejskiej zainteresowanie dotacjami z funduszy unijnych na podniesienie konkurencyjności sektora MSP poprzez inwestycje i rozwój kapitału ludzkiego ciągle rośnie, osiągając wręcz poziom głównego determinantu, od którego właściciele firm uzależniają dalszy rozwój.

Prowadzenie działalności gospodarczej na rynku wspólnotowym cechuje przede wszystkim nowoczesne zarządzanie, łączące się bezpośrednio z innowacyjnością kapitałową i produktową. Możliwość pozyskania środków zewnetrznych (w formie dotacji) to obecnie najistotniejszy element finansowania firmy, gdyż dzięki niemu istnieje możliwość obniżenia kosztów związanych m.in. z: promocją, modernizacją technologiczną oraz rozwojem kadr i własnych pracowników. Analizując zrealizowane formy dotacji od 2004 roku, można stwierdzić jednoznacznie, że jednym z głównych odbiorców tej formy interwencji finansowej ze środków unijnych jest sektor mikro-, małych i średnich przedsiębiorstw (MSP), który zarówno w Polsce, jak i w całej Unii Europejskiej odgrywa kluczową rolę w rozwoju gospodarczym państwa.

W literaturze przedmiotu rolę MSP w życiu społeczno-gospodarczym regionu rozpatruje się pod względem: rozwoju innowacyjności, zatrudnienia, rozwoju produktu lokalnego, skutecznego radze- nia sobie przez małe firmy z kryzysem finansowo-gospodarczym (Sasin, 2003). M. Oliński twierdzi natomiast, że: „Małe i średnie przedsiębiorstwa spełniają wiele pozytywnych funkcji, które dzielimy na społeczne i gospodarcze. Podstawową funkcją społeczna (...) jest formowanie samodzielnej ekonomicznie klasy średniej (...), powszechnie uważa się bowiem, że dobrobyt państwa oraz sprawne funkcjonowanie mechanizmu rynkowego zależy od stopnia rozwoju klasy średniej w danym społeczeństwie".

W Polsce w 2014 roku działało niecałe $1,8 \mathrm{mln}$ przedsiębiorstw. MSP stanowiły aż $99,8 \%$ tych podmiotów i zatrudniały blisko 7 mln osób, czyli ok. $62 \%$ wszystkich zatrudnionych w przedsiębiorstwach. Według danych GUS w Polsce zauważalna jest wyraźna dominacja, w ogólnej liczbie pracujących w przedsiębiorstwach, osób pracujacych w mikro- i małych firmach ok. 52\%, w średnich niecałe 18\% (GUS, dostep 1.08.2016 r.). Małe i średnie przedsiębiorstwa wytwarzają w Polsce ok. $44 \%$ PKB (Eurostat, dostęp 1.08.2016 r.). Tak dobra dynamika rozwoju tego sektora gospodarki możliwa jest dzięki stworzeniu przyjaznych warunków społecznych i ekonomicznych. Obszar funkcjonowania MSP zarówno w Polsce, jak i w całej UE jest silnie zróżnicowany, funkcjonuje w sektorach tradycyjnych, a także bardzo nowoczesnych. Mikro- i małe przedsiębiorstwa dominują tam, gdzie koszt utworzenia miejsca pracy 
jest niski, czyli w takich usługach, jak handel, gastronomia oraz serwis. Znaczenie sektora MSP dla rozwoju gospodarki nie ogranicza się tylko do ich udziału w tworzeniu PKB i miejsc pracy. Głównym atutem tych firm jest ich elastyczność na zmieniające się warunki otoczenia, w których funkcjonują. Dzięki umiejętności dopasowywania posiadanych zasobów do warunków flextime (elastyczny czas pracy) czy też szybkim zmianom organizacyjnym, zarządczym, właściwemu doborowi odbiorców oraz wykorzystaniu narzędzi marketingowych, sektor mikro- i małych przedsiębiorstw potrafi szybko reagować na potrzeby coraz bardziej wymagających klientów.

Jak twierdzi M. Hryniewicka (2015), „(...) przedsiębiorstwa obok instytucji finansowych, są motorem napędowym całej gospodarki (...). Przyczyniają się do rozwoju lub stagnacji całego regionu. Należy podkreślić, że rozwój regionalny jest m.in. uzależniony od rozwoju przedsiębiorczości, inwestycji i zatrudnienia". Biorąc więc pod uwage powyższe czynniki, można stwierdzić, że sektor MSP jest jednym z głównych determinantów rozwoju regionu i wpływa bezpośrednio na poniesienie jego konkurencji na rynku wspólnotowym. Najszybciej reaguje też na zmieniające się otoczenie, a jedną $\mathrm{z}$ głównych jego cech jest mobilność (tak obecnie istotna na rynku wspólnotowym) oraz elastyczność, zwłaszcza zatrudnieniowa. Pod względem społecznym przedsiebiorstwa MSP stanowia fundament rozwoju klasy średniej oraz skutecznie potrafia przystosować się do gustów konsumenckich (Wolański, 2013).

Celem niniejszego artykułu jest identyfikacja, porównanie i ocena wykorzystania wybranych form wsparcia rozwoju przedsiębiorczości z funduszy UE oraz zaprezentowanie wyników badania ankietowego, które zostało zrealizowane w 2014 roku na 277 respondentach. Na potrzeby tego badania sformułowano następujący problem badawczy oraz hipotezę.

Problem badawczy: czy inwestycja w rozwój firmy mogłaby zostać zrealizowana $\mathrm{z}$ innych środków niż fundusze unijne, a jeżeli nie - to dlaczego?

Hipoteza badawcza stwierdza, że badane osoby wysoko oceniają znaczenie środków unijnych jako stymulatorów rozwoju przedsiębiorczości, jak też uzależniają decyzję inwestycyjną od otrzymania dotacji z funduszy unijnych.
Struktura artykułu została podzielona na dwie części. W części pierwszej, zatytułowanej „Wsparcie sektora MSP z perspektywy oddziaływania wybranych funduszy unijnych" omówiono stan sektora MSP, podstawowe pojęcia związane z polityką regionalna/spójności i jej oddziaływaniem na rozwój sektora MSP. Ponadto przeprowadzono analizę i porównanie wybranych form wsparcia mikro-, małych i średnich firm $\mathrm{z}$ funduszy unijnych od $2004 \mathrm{r}$. W podsumowaniu tego rozdziału przybliżono nową perspektywę finansową na lata 2014-2020 ze szczególnym uwzględnieniem działań wspierających rozwój sektora MSP oraz zaprezentowano podstawowe bariery w dostępie do tej formy interwencji finansowej.

W części drugiej autor przedstawił wyniki zrealizowanych badań, związanych z opinią respondentów na temat: czy zaplanowana inwestycja zostałaby zrealizowana $z$ innych środków niż fundusze unijne, a jeżeli nie - to dlaczego?

\section{Wsparcie sektora MSP z perspektywy oddziaływania wybranych funduszy unijnych}

Ze względu na rolę, jaką odgrywają mikro-, małe i średnie firmy w rozwoju gospodarczym regionów, zarówno w programach przedakcesyjnych, jak i po akcesji Polski do UE, przewidziano szerokie i zróżnicowane formy wsparcia finansowego w formie dotacji oraz pożyczek. Na rynku unijnym sektor MSP uznaje się za źródło konkurencyjności europejskiej gospodarki i wzrostu gospodarczego, ponieważ mikro-, małe i średnie firmy przyczyniają się do rozwoju współpracy międzynarodowej, wdrażania innowacji społecznych i technologicznych, podnoszenia konkurencyjności międzyregionalnej oraz poprawy warunków życia.

W wyniku członkostwa Polski w strukturach Unii Europejskiej polskie przedsiębiorstwa zyskały nie tylko dostęp do nowych rynków zbytu i pole do szerszej ekspansji eksportowej, lecz także ogromną szanse na rozwój, dzięki funduszom unijnym umożliwiającym wyrównanie spójności ekonomicznej i społecznej poszczególnych regionów Polski.

Według raportu PARP pt.: „Stan sektora małych i śrenich przedsiębiorstw w Polsce 
w latach 2013-2014", sytuacja finansowa przedsiębiorstw po akcesji Polski do UE bardzo się poprawiła. Firmy odnotowały znaczne korzyści finansowe. Poprawiły się podstawowe wskaźniki ekonomiczno-finansowe. Nakłady inwestycyjne na rozwój sektora MSP wzrosły z 45 mln PLN w 2004 roku do 79 mln PLN w 2013 roku, tj. o ok. 75\%. Adekwatnie we wspomnianym okresie wzrósł eksport wyrobów sektora MSP do krajów UE z ok. 302 mld PLN do 485 mld PLN, tj. o ok. 60\%. Przeciętne wynagrodzenie z perspektywy ostatniej dekady wzrosło z 3.027,00 do 3.850,00 PLN, tj. o 27,2\%.

Opisana kondycja sektora MSP przekłada się bezpośrednio na wysoką liczbe osób, które decydują się na założenie własnej działalności gospodarczej. Firmy jedno-, dwu- i trzyletnie stanowią razem aż $28 \%$ całego sektora. Pod względem udziału firm jednorocznych i dwuletnich zajmujemy odpowiednio 4 i 1 miejsce w UE (PARP, 2015).

Dzięki środkom unijnym, dostępnym w ramach różnych programów operacyjnych, bezpośrednio kierowanych do przedsiębiorców i ich otoczenia, jesteśmy postrzegani jako kraj tworzący przyjazne warunki do prowadzenia działalności gospodarczej, co nie tylko przekłada się na poziom absorpcji, lecz także na efektywność wydatkowania wsparcia unijnego. Najlepiej opisuje to „Wskaźnik prowadzenia działalności gospodarczej” stosowany przez Bank Światowy. Do 2015 r. uwzględniał on 10 aspektów (od 2016 r. - 11 aspektów) ${ }^{1}$, które pozwalają ocenić, w jaki sposób przepisy dotyczace prowadzenia działalności gospodarczej wpływają na stan sektora MSP w 189 krajach. W rankingu dotyczącym łatwości prowadzenia działalności gospodarczej, w którym to sytuacja idealna $=100$, Polska w 2006 roku (czyli w drugim roku korzystania z funduszy unijnych) uzyskała zaledwie 58 punktów (co dawało 54 pozycje), natomiast w 2015 r. - 78 punktów, co oznacza 20 punktowy wzrost i 25 (najlepszą) pozycję $\mathrm{w}$ rankingu. Tabela 1 przedstawia pozycję Polski w stosunku do 28 krajów UE z roku 2006 i 2015 pod względem warunków dot. zakładania firmy - brano pod uwage obowiazujace procedury, czas oraz wymagany minimalny wkład początkowy.

Tabela 1 zawiera porównanie do wzorca, uosabiającego najlepsze praktyki prowadzenia działalności w badanej grupie (distance to frontier - DTF). Realizacja najlepszych praktyk oznacza 100 punktów, dlatego im niższa wartość DTF, tym większy dystans od wzoru najlepszych praktyk w danej kategorii (Rapkiewicz i Fijałkowski, 2016).

Analizując dane $\mathrm{z}$ tabeli $1 \mathrm{w}$ kategorii zakładanie działalności gospodarczej, możemy wywnioskować, że w Polsce, pomimo zmian, jakie nastapiły w okresie ostatnich 10 lat, proces zakładania firmy nadal nie należy do najprostszych. Według omawianego wskaźnika najbardziej przyjaznym krajem w 2006 r. była Belgia, a w 2015 r. - Litwa. Analogicznie 21 i 24 miejsce Polski to przede wszystkim skutek niewdrożenia pełnych procedur e-administracji oraz zbyt niska powszechność e-podpisu, co inkubuje zbyt rozbudowane procesy administracyjne.

Oczywiście nie można w sposób jednoznaczny określić bezpośredniego oddziaływania funduszy unijnych na ranking Doing Business. Należy jednak zwrócić uwagę, że zrealizowane przez sektor MSP inwestycje wspierały jego rozwój i wzrost konkurencyjności, a wysoka absorpcja funduszy unijnych może okazać się ważnym czynnikiem dostępności do zewnętrznych źródeł finansowania (Mikołajczyk, 2012).

\subsection{Polityka regionalna}

\section{i jej wpływ na rozwój sektora MSP}

$\mathrm{Za}$ jeden $\mathrm{z}$ najważniejszych mechanizmów oddziałujacych na zmniejszenie nierówności w rozwoju regionalnym uważana jest polityka regionalna Unii Europejskiej, której celem nadrzędnym jest wyrównanie dysproporcji w rozwoju gospodarczym i społecznym poprzez niwelowanie różnic i osiagganie spójności między poszczególnymi regionami. W tym zakresie polityka regionalna utożsamiana jest często $\mathrm{z}$ polityką spójności, gdyż ma na celu zmniejszenie różnic w poziomie rozwoju gospodarczego między poszczególnymi regionami².

W teoretycznym sporze dotyczącym oddziaływania polityki regionalnej pojawiają się dwie przeciwstawne koncepcje: pierwsza z nich tzw. wyrównawcza, druga - polaryzacyjna (Bachtler, 1996). Zwolennicy wariantu wyrównawczego opowiadają się za interwencją państwa, którą należy skierować do regionów najbiedniejszych. Celem tej interwencji byłaby restrukturyzacja gospodarki, która powinna się przyczynić do zwiększenia dynamiki wzrostu 
Tabela 1. Ranking Doing Business w kategorii zakładanie działalności gospodarczej

\begin{tabular}{|c|c|c|c|c|c|}
\hline \multicolumn{3}{|c|}{2006 r. } & \multicolumn{3}{|c|}{2015 r. } \\
\hline $\begin{array}{c}\text { Miejsce } \\
\text { w rankingu }\end{array}$ & Kraj & $\begin{array}{c}\text { DTF - liczba } \\
\text { punktów }\end{array}$ & $\begin{array}{c}\text { Miejsce } \\
\text { w rankingu }\end{array}$ & Kraj & $\begin{array}{c}\text { DTF - liczba } \\
\text { punktów }\end{array}$ \\
\hline 1 & Belgia & 94,31 & 1 & Litwa & 97,70 \\
\hline 2 & Finlandia & 93,10 & 2 & Portugalia & 96,28 \\
\hline 3 & Węgry & 93,07 & 3 & Estonia & 95,06 \\
\hline 4 & Słowenia & 92,97 & 4 & Szwecja & 94,62 \\
\hline 5 & Francja & 92,50 & 5 & $\begin{array}{c}\text { Wielka } \\
\text { Brytania }\end{array}$ & 94,57 \\
\hline 6 & Irlandia & 92,41 & 6 & Słowenia & 94,53 \\
\hline 7 & Dania & 91,79 & 7 & Belgia & 94,50 \\
\hline 8 & Rumunia & 91,58 & 8 & Irlandia & 94,18 \\
\hline 9 & Szwecja & 91,31 & 9 & Łotwa & 94,15 \\
\hline 10 & Estonia & 90,95 & 10 & Holandia & 94,14 \\
\hline 11 & Portugalia & 90,22 & 11 & Dania & 94,04 \\
\hline 12 & $\begin{array}{c}\text { Wielka } \\
\text { Brytania }\end{array}$ & 90,04 & 12 & Francja & 93,14 \\
\hline 13 & Bułgaria & 89,68 & 13 & Finlandia & 93,11 \\
\hline 14 & Cypr & 89,30 & 14 & Rumunia & 91,94 \\
\hline 15 & Lotwa & 89,20 & 15 & Włochy & 91,13 \\
\hline 16 & Włochy & 87,42 & 16 & Bułgaria & 91,10 \\
\hline 17 & Holandia & 86,97 & 17 & Grecja & 90,70 \\
\hline 18 & Słowacja & 86,63 & 18 & Węgry & 90,56 \\
\hline 19 & Luksemburg & 85,52 & 19 & Cypr & 89,23 \\
\hline 20 & Litwa & 82,52 & 20 & Słowacja & 88,54 \\
\hline 21 & Polska & 81,70 & 21 & Luksemburg & 86,46 \\
\hline 22 & Chorwacja & 81,48 & 22 & Hiszpania & 86,30 \\
\hline 23 & $\begin{array}{c}\text { Republika } \\
\text { Czeska }\end{array}$ & 81,03 & 23 & Chorwacja & 86,21 \\
\hline 24 & Niemcy & 80,82 & 24 & Polska & 85,94 \\
\hline 25 & Austria & 79,67 & 25 & $\begin{array}{c}\text { Republika } \\
\text { Czeska }\end{array}$ & 85,23 \\
\hline 26 & Malta & 74,30 & 26 & Austria & 83,45 \\
\hline 27 & Grecja & 70,90 & 27 & Niemcy & 83,37 \\
\hline 28 & Hiszpania & 68,88 & 28 & Malta & 78,43 \\
\hline
\end{tabular}

Źródło: opracowanie własne na podstawie: http://www.doingbusiness.org (01.08.2016).

i uruchomienia procesu „doganiania” obszarów (regionów) bogatych. Zwolennicy wariantu polaryzacyjnego uważają, że wszelka ingerencja narusza mechanizm rynkowy, który jest najbardziej efektywny. W opinii reprezentantów tej opcji jakakolwiek interwencja państwa nie tylko nie jest w stanie pomóc regionom słabszym, lecz także może być przyczyną ich niedorozwoju (Levison, 1992) 3 .

Za punkt zwrotny w kształtowaniu się europejskiej polityki regionalnej/spójności uważa się reformę Europejskiego Funduszu Rozwoju Regionalnego (EFRR), która 
została przeprowadzona w 1979 roku. Wprowadzono wtedy zasady programowania interwencji i odejścia od wspierania przez Unię pojedynczych projektów na rzecz współfinansowania kompleksowych, zintegrowanych i mających wieloletni charakter planów rozwoju. Ewolucji podlegała tak sama jej koncepcja, jak i jej cele oraz instrumenty finansowe. Ewolucję celów i instrumentów finansowych polityki regionalnej prezentuje tabela 2 .

Tabela 2 przedstawia jak ewoluowały fundusze unijne oraz cele polityki rozwoju regionalnego w różnych okresach programowania. Najważniejszym celem dla Polski jest Cel 1 skierowany do regionów o PKB per capita mniejszym niz $75 \%$ średniej unijnej (tzn. regionów nierozwi- niętych $)^{4}$. Interwencje finansowe realizowane w ramach tego celu mają za zadanie zwiększenie spójności najsłabiej rozwiniętych państw członkowskich i regionów, poprzez poprawe warunków dla wzrostu gospodarczego i zwiększania zatrudnienia m.in. poprzez rozwój sektora MSP. Zrealizowane formy wsparcia $\mathrm{z}$ dwóch głównych funduszy unijnych, tj. Europejskiego Funduszu Społecznego ${ }^{5}$ i Europejskiego Funduszu Rozwoju Regionalnego ${ }^{6}$, umożliwiły wzrost konkurencyjności, zdobycie nowych inwestorów, zwiększenie możliwości produkcyjnych, implementację innowacyjnych rozwiązań technologicznych. Reasumując, polityka rozwoju regionalnego wobec MSP od samego początku oferowała i nadal oferuje różnorodne formy pomocy, które

Tabela 2. Porównanie celów i instrumentów finansowych (funduszy unijnych) polityki regionalnej 2000-2020

\begin{tabular}{|c|c|c|c|}
\hline & $2000-2006$ & 2007-2013 & 2014-2020 \\
\hline \multirow[t]{3}{*}{ Cel } & $\begin{array}{l}\text { Cel } 1 \\
\text { Promocja rozwoju } \\
\text { i dostosowanie } \\
\text { strukturalne regionów } \\
\text { słabo rozwiniętych }\end{array}$ & $\begin{array}{l}\text { Cel } 1 \\
\text { Konwergencja }\end{array}$ & $\begin{array}{l}\text { Cel } 1 \\
\text { Inwestycje w rozwój } \\
\text { gospodarczy i wzrost } \\
\text { zatrudnienia }\end{array}$ \\
\hline & $\begin{array}{l}\text { Cel } 2 \\
\text { Wzmocnienie społecznej } \\
\text { i gospodarczej } \\
\text { transformacji regionów } \\
\text { przeżywających kryzys } \\
\text { strukturalny }\end{array}$ & $\begin{array}{l}\text { Cel } 2 \\
\text { Konkurencyjność } \\
\text { i zatrudnienie }\end{array}$ & $\begin{array}{l}\text { Cel } 2 \\
\text { Europejska } \\
\text { współpraca } \\
\text { terytorialna }\end{array}$ \\
\hline & $\begin{array}{l}\text { Cel } 3 \\
\text { Pomoc w adaptacji } \\
\text { i modernizacji polityki } \\
\text { i systemu edukacji, } \\
\text { szkoleń i zatrudnienia }\end{array}$ & $\begin{array}{l}\text { Cel } 3 \\
\text { Europejska } \\
\text { współpraca } \\
\text { terytorialna }\end{array}$ & \\
\hline \multirow[t]{4}{*}{ Fundusze } & $\begin{array}{l}\text { Europejski Fundusz } \\
\text { Społeczny (EFS) }\end{array}$ & $\begin{array}{l}\text { Europejski Fundusz } \\
\text { Społeczny (EFS) }\end{array}$ & $\begin{array}{l}\text { Europejski Fundusz } \\
\text { Społeczny (EFS) }\end{array}$ \\
\hline & $\begin{array}{l}\text { Europejski Fundusz } \\
\text { Rozwoju } \\
\text { Regionalnego (EFRR) }\end{array}$ & $\begin{array}{l}\text { Europejski Fundusz } \\
\text { Rozwoju } \\
\text { Regionalnego (EFRR) }\end{array}$ & $\begin{array}{l}\text { Europejski Fundusz } \\
\text { Rozwoju } \\
\text { Regionalnego (EFRR) }\end{array}$ \\
\hline & $\begin{array}{l}\text { Europejski Fundusz } \\
\text { Orientacji i Gwarancji } \\
\text { Rolnej (EFOiGR) }\end{array}$ & Fundusz Spójności (FS) & Fundusz Spójności (FS) \\
\hline & $\begin{array}{l}\text { Finansowy Instrument } \\
\text { Orientacji Rybołówstwa } \\
\text { (FIOR) }\end{array}$ & & \\
\hline
\end{tabular}

Źródło: opracowanie własne na podstawie dokumentów programowych. 
mają zasięg regionalny i ponadnarodowy. Dzięki przyjętym regulacjom, takim jak np. harmonizacja prawa, stosowanie zasad uczciwej konkurencji czy też liberalizacji handlu, nasz sektor MSP może z powodzeniem konkurować na rynku unijnym, a co najważniejsze - efektywnie wpływać na rozwój regionów.

O tym jak ważnym sektorem, nie tylko dla Polski, lecz także dla Unii Europejskiej, są mikro- i małe przedsiębiorstwa świadczą uruchamiane programy, w których polscy przedsiębiorcy brali czynny udział. Jednym z nich był program „Small Business Act”. Jego głównym celem była promocja przedsiębiorczości, a określono w nim 10 zasad wspierających MSP we wzroście oraz tworzeniu miejsc pracy, m.in.: stworzenie warunków (w tym prawnych i finansowych), w których przedsiębiorcy i przedsiębiorstwa rodzinne mogą dobrze prosperować; zagwarantowanie przedsiębiorcy, którego przedsiębiorstwo zostało postawione w stan upadłości, możliwość szybkiego otrzymania „drugiej szansy”; sprawienie, by organy administracji publicznej lepiej reagowały na potrzeby MSP; ułatwianie dostępu do finansowania oraz wspieranie podnoszenia kwalifikacji i innowacji.

Kolejnym programem wspierającym sektor MSP jest program COSME (uruchomiony 1 stycznia 2014 roku i otwarty do 31 grudnia 2020 r.). Celem głównym programu jest wzmocnienie konkurencyjności MSP i krzewienie kultury przedsiębiorczości. Cel główny ma być osiągnięty w wyniku realizacji następujących celów szczegółowych: poprawa dostępu do instrumentów finansowych, poprawa warunków konkurencyjności i promocja przedsiębiorczości. W ramach programu COSME nasi przedsiębiorcy będą mogli realizować projekty, które umożliwią wdrożenie nowoczesnych technologii, wymiane doświadczeń poprzez propagowanie ponadnarodowej współpracy klastrów i sieci biznesowych, odbudowe usług „niszowych”, cyfryzację sektora MSP oraz wprowadzenie „unikalnych” nowych produktów i usług.

Bilansując działania, jakie wdrożyła i stosuje Unia Europejska wobec sektora MSP, możemy podzielić je na trzy główne kierunki, tj.: ograniczenie ilości procedur administracyjnych i podatkowych, modyfikację prawa handlowego ze szczególnym uwzględnieniem dyrektywy dotyczące

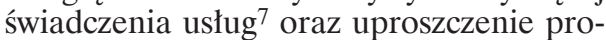

cedur w pozyskiwaniu środków z funduszy strukturalnych UE (Rozporządzenie PE i Rady (UE) Nr 1287/2013, Dz. Urz. UE L 347).

\subsection{Analiza wybranych form wsparcia sektora MSP z funduszy unijnych}

Na potrzeby niniejszego artykułu analiza wybranych form wsparcia rozwoju sektora MSP z funduszy unijnych została podzielona na trzy okresy programowania, dla których zostały wybrane najistotniejsze (zdaniem autora) programy, umożliwiające zwiększenie udziału sektora MSP w generowaniu produktu krajowego brutto oraz podniesieniu konkurencyjność polskich regionów. Cechą wspólną funduszy unijnych dla wszystkich poniżej przeanalizowanych okresów programowania jest:

1) obowiazek wykorzystania otrzymanej dotacji na ściśle określone we wniosku o dofinansowanie;

2) posiadanie wkładu własnego, który nie musi mieć formy pieniężnej, może to być np. gwarancja bankowa;

3) szeroki wachlarz możliwości inwestycyjnych, przedsiębiorca może wykorzystać otrzymane środki, m.in. na inwestycje w sprzęt i urządzenia, promocję ponadregionalną oraz rozwój swoich pracowników;

4) priorytetowe traktowanie (na etapie programowania) sektora MSP ze szczególnym uwzględnieniem mikro- i małych firm;

5) refinansowa forma otrzymanej dotacji, co oznacza w praktyce konieczność poniesienia kosztów inwestycji ze środków własnych, a dopiero po rozliczeniu - ich zwrot;

6) aplikowanie o środki UE na podstawie złożonych projektów przygotowanych w tzw. generatorach wniosków aplikacyjnych.

\subsubsection{Pierwszy okres programowania 2004-2006}

Podstawowym dokumentem wprowadzającym zasady wykorzystania funduszy unijnych na lata 2004-2006 był Narodowy Plan Rozwoju (NPR) ${ }^{8}$. Realizacji NPR służyło m.in. 5 sektorowych programów operacyjnych, jeden zintegrowany program operacyjny i pomoc techniczna. Alokację środków pomiędzy poszczególne programy prezentuje tabela 3 . 
Tabela 3. Alokacja środków pomiędzy programy operacyjne

\begin{tabular}{|l|c|}
\hline \multicolumn{1}{|c|}{ Program operacyjny } & Alokacja środków w mln euro \\
\hline $\begin{array}{l}\text { Zintegrowany Program Operacyjny Rozwoju Regionalnego } \\
\text { (ZPORR) }\end{array}$ & 2968 \\
\hline $\begin{array}{l}\text { Sektorowy Program Operacyjny Wzrost Konkurencyjności } \\
\text { Przedsiębiorstw (SPO WKP) }\end{array}$ & 1251 \\
\hline $\begin{array}{l}\text { Sektorowy Program Operacyjny Rozwój Zasobów Ludzkich } \\
\text { (SPO RZL) }\end{array}$ & 1470 \\
\hline Sektorowy Program Operacyjny Transport (SPOT) & 1193 \\
\hline $\begin{array}{l}\text { Sektorowy Program Operacyjny „Restrukturyzacja } \\
\text { i modernizacja sektora żywnościowego oraz rozwój obszarów } \\
\text { wiejskich” (SPO ROL) }\end{array}$ & 0,21 \\
\hline $\begin{array}{l}\text { Sektorowy Program Operacyjny „Rybołówstwo i Przetwórstwo } \\
\text { Ryb” (SPO Ryby) }\end{array}$ & 0,03 \\
\hline Program Operacyjny Pomoc Techniczna 2004-2006 (PO PT) & \\
\hline
\end{tabular}

Źródło: opracowanie własne na podstawie sprawozdania końcowego z realizacji NPR.

Do najważniejszych programów skierowanych do sektora MSP w tym okresie programowania zaliczamy: Sektorowy Program Operacyjny Wzrost Konkurencyjności Przedsiębiorstw (SPO WKP), Zintegrowany Program Operacyjny Rozwoju Regionalnego (ZPORR) oraz Sektorowy Program Operacyjny Rozwój Zasobów Ludzkich (SPO RZL). Priorytety skierowane do przedsiębiorców oraz wartość zrealizowanego dofinansowania prezentuje tabela 4.

Analizując efekty wsparcia sektora MSP na podstawie tabeli 4, zauważyć należy, że wszystkie zaplanowane działania wspierające rozwój i konkurencyjność mikro-, małych i średnich firm cieszyły się bardzo dużym zainteresowaniem, a na koniec okresu programowania (2006 r.) osiągnięto wykorzystanie na średnim poziomie $102,5 \%$. Zdecydowanie najwyższy wskaźnik $(108,9 \%)$ uzyskało Działanie 2.1. Wzrost konkurencyjności małych i średnich przedsiębiorstw poprzez doradztwo. Realizacja SPO WKP spowodowała m.in. powstanie ok. 38 tys. nowych miejsc pracy; dofinansowano 65 instytucji $\mathrm{z}$ otoczenia biznesu; udzielono wsparcia 27 parkom przemysłowym, 17 parkom naukowo-technologicznym oraz 19 inkubatorom technologicznym; zrealizowano 80 projektów celowych, polegających na prowadzeniu badań naukowych mających praktyczne zastosowanie w gospodarce; 398 przedsiębiorstw wdrożyło nowe technologie, dzięki wsparciu w zakresie specjalistycznych usług doradczych; ze wsparcia na inwestycje skorzystało 3220 przedsiębiorstw, w tym 3186 z sektora MSP (MRR, 2009).

Celem ZPORR było podniesienie konkurencyjności regionów oraz przeciwdziałanie ich marginalizacji. Z perspektywy wsparcia sektora MSP cel ten został zrealizowany przez takie działania, jak:

1) stworzenie warunków dla rozwoju zasobów ludzkich na poziomie lokalnym i regionalnym, a także poprawe zdolności do programowania i realizacji projektów w zakresie rozwoju zasobów ludzkich;

2) wsparcie zatrudnienia poprzez stymulowanie powstawania nowych mikroprzedsiębiorstw oraz zapewnienie nowo zarejestrowanym mikroprzedsiębiorcom pomocy w wykorzystaniu dostępnych instrumentów wsparcia;

3) zwiększenie konkurencyjności mikroprzedsiębiorstw poprzez ułatwienie dostępu do specjalistycznego doradztwa oraz zwiększenie zdolności inwestycyjnej w początkowym okresie funkcjonowania.

Z Działania 3.4. Mikroprzedsiebiorstwa skorzystało blisko 3000 firm, które otrzymały dotację na specjalistyczne usługi doradcze oraz pomoc inwestycyjną obejmująca zakup środków trwałych i modernizację lokali, w których prowadzona ma być działalność gospodarcza. Zrealizowano 378 projektów. Szkoleniami objęto 
Tabela 4. Priorytety, działania skierowane do przedsiębiorców $i$ wartość zrealizowanego dofinansowania

\begin{tabular}{|c|c|c|c|}
\hline Priorytet/działanie & $\begin{array}{c}\text { Alokacja } \\
\text { w mln PLN }\end{array}$ & $\begin{array}{l}\text { Wykorzystanie } \\
\text { w mln PLN }\end{array}$ & $\begin{array}{l}\text { Wykorzystanie } \\
\text { alokacji w \% }\end{array}$ \\
\hline \multicolumn{4}{|c|}{ Sektorowy Program Operacyjny Wzrost Konkurencyjności Przedsiębiorstw (SPO WKP) } \\
\hline \multicolumn{4}{|c|}{$\begin{array}{c}\text { Priorytet 1. Rozwój przedsiębiorczości i wzrost innowacyjności } \\
\text { poprzez wzmocnienie instytucji otoczenia biznesu }\end{array}$} \\
\hline $\begin{array}{l}\text { Działanie 1.1. Wzmocnienie instytucji } \\
\text { wspierających działalność przedsiębiorstw }\end{array}$ & 139,8 & 142,3 & 101,8 \\
\hline $\begin{array}{l}\text { Działanie 1.2. Poprawa dostępności do } \\
\text { zewnętrznego finansowania inwestycji } \\
\text { przedsiębiorstw }\end{array}$ & 753,3 & 766,9 & 101,8 \\
\hline $\begin{array}{l}\text { Działanie } 1.3 \text {. Tworzenie korzystnych } \\
\text { warunków dla rozwoju firm }\end{array}$ & 634,7 & 706,4 & 111,3 \\
\hline $\begin{array}{l}\text { Działanie 1.4. Wzmocnienie współpracy } \\
\text { między sferą badawczo-rozwojową } \\
\text { a gospodarką }\end{array}$ & 510,2 & 525,5 & 103,0 \\
\hline $\begin{array}{l}\text { Działanie 1.5. Rozwój systemu dostępu } \\
\text { przedsiębiorców do informacji i usług } \\
\text { publicznych on-line }\end{array}$ & 395,6 & 423,3 & 107,0 \\
\hline \multicolumn{4}{|l|}{$\begin{array}{l}\text { Priorytet 2. Bezpośrednie wsparcie } \\
\text { przedsiębiorstw }\end{array}$} \\
\hline $\begin{array}{l}\text { Działanie 2.1. Wzrost konkurencyjności } \\
\text { małych i średnich przedsiębiorstw poprzez } \\
\text { doradztwo }\end{array}$ & 54,8 & 59,7 & 108,9 \\
\hline $\begin{array}{l}\text { Działanie 2.2. Wsparcie konkurencyjności } \\
\text { produktowej i technologicznej } \\
\text { przedsiębiorstw }\end{array}$ & 1104,0 & 1104,8 & 100,0 \\
\hline $\begin{array}{l}\text { Działanie 2.3. Wzrost konkurencyjności } \\
\text { małych i średnich przedsiębiorstw poprzez } \\
\text { inwestycje }\end{array}$ & 1449,5 & 1484,3 & 102,4 \\
\hline $\begin{array}{l}\text { Działanie 2.4. Wsparcie dla przedsięwzięć } \\
\text { w zakresie dostosowania przedsiębiorstw do } \\
\text { wymogów ochrony środowiska }\end{array}$ & 713,5 & 733,5 & 102,8 \\
\hline \multicolumn{4}{|c|}{ Zintegrowany Program Operacyjny Rozwoju Regionalnego (ZPORR) } \\
\hline \multicolumn{4}{|c|}{ Priorytet 2. Wzmocnienie rozwoju zasobów ludzkich $w$ regionach } \\
\hline $\begin{array}{l}\text { Działanie 2.1. Rozwój umiejętności } \\
\text { powiązany z potrzebami regionalnego rynku } \\
\text { pracy i możliwości kształcenia ustawicznego } \\
\text { w regionie }\end{array}$ & 431,3 & 427,6 & 99,14 \\
\hline Działanie 2.5. Promocja przedsiębiorczości & 176,6 & 175,5 & 99,38 \\
\hline \multicolumn{4}{|c|}{ Priorytet 3. Rozwój lokalny } \\
\hline Działanie 3.4. Mikroprzedsiębiorstwa & 168,4 & 175,8 & 104,39 \\
\hline \multicolumn{4}{|c|}{ Sektorowy Program Operacyjny Rozwój Zasobów Ludzkich (SPO RZL) } \\
\hline \multicolumn{4}{|c|}{ Priorytet 2. Bezpośrednie wsparcie przedsiębiorstw } \\
\hline $\begin{array}{l}\text { Działanie 2.3. Rozwój kadr nowoczesnej } \\
\text { gospodarki }\end{array}$ & 760,7 & 697,9 & 91,74 \\
\hline
\end{tabular}

Źródło: opracowanie własne na podstawie sprawozdań końcowych z SPO WKP, ZPORR i SPO RZL.

Wydział Zarządzania UW ～DOI 10.7172/1733-9758.2017.23.13 
18,2 tys. osób, z doradztwa skorzystało ok 15,9 tys. osób, ze wsparcia pomostowego - 7,3 tys. osób, a jednorazowe dotacje na otwarcie działalności gospodarczej otrzymało 7,2 tys. osób (MRR, 2010).

\subsubsection{Drugi okres programowania 2007-2013}

Efektem realizacji wsparcia $z$ funduszy unijnych po pierwszym okresie programowania jest przede wszystkim bezpośrednie wsparcie przedsiębiorstw, w tym m.in wdrożenie nowych technologii, co przyczyniło się do poprawy warunków funkcjonowania sektora MSP, a przez to do wzrostu jego konkurencyjności. Realizacja projektów służących rozwojowi zasobów ludzkich przełożyła się na dopływ wysoko wykwalifikowanych kadr do gospodarki i podniesienie jakości pracowników w sektorze MSP.

$\mathrm{W}$ drugim okresie programowania Polska miała do dyspozycji prawie $60 \mathrm{mld}$ euro. Była to najwyższa alokacja spośród wszystkich państw członkowskich (kolejna Hiszpania ok. 36 mld euro). Zasady programowania i wykorzystania funduszy unijnych w okresie 2007-2014 zostały zapisane w Narodowej Strategii Spójności (NSS) (nazwa urzedowa: Narodowe Strategiczne Ramy Odniesienia - NSRO ${ }^{9}$ ). Działania skierowane do przedsiębiorców zostały zawarte w ramach następujących Programów Operacyjnych (PO): PO Innowacyjna Gospodarka (PO IG), PO Kapitał Ludzki (PO KL), PO Rozwój Polski Wschodniej (PO RPW) oraz Regionalne Programy Operacyjne (RPO). Tabela 5 prezentuje najistotniejsze (zdaniem autora) działania z perspektywy rozwoju sektora MSP.

Analizując wyniki z tabeli 5, możemy zauważyć, że, tak jak w poprzednim okresie programowania, wykorzystanie środków alokowanych do działań skierowanych do sektora MSP jest bardzo wysokie, gdyż średnia ze wszystkich form wsparcia prze-

Tabela 5. Priorytety, działania skierowane do przedsiębiorców i wartość zrealizowanego dofinansowania

\begin{tabular}{|l|c|c|c|}
\hline \multicolumn{1}{|c|}{ Priorytet/działanie/poddziałanie } & $\begin{array}{c}\text { Alokacja } \\
\text { w mln PLN }\end{array}$ & $\begin{array}{c}\text { Wykorzystanie } \\
\text { w mln PLN }\end{array}$ & $\begin{array}{c}\text { Wykorzystanie } \\
\text { alokacji w \% }\end{array}$ \\
\hline \multicolumn{3}{|c|}{ Program Operacyjny Innowacyjna Gospodarka (PO IG) } \\
\hline $\begin{array}{l}\text { Działanie 1.3. Wsparcie projektów B+R } \\
\text { na rzecz przedsiębiorców realizowanych } \\
\text { przez jednostki naukowe }\end{array}$ & 1596,6 & 1492,1 & 93,45 \\
\hline Działanie 1.4. Wsparcie projektów celowych & 1871,7 & 1743,2 & 93,13 \\
\hline \multicolumn{3}{|c|}{ Priorytet 3. Kapitat dla innowacji } \\
\hline $\begin{array}{l}\text { Działanie 3.1. Inicjowanie działalności } \\
\text { innowacyjnej (nowe MSP) }\end{array}$ & 813,4 & 741,3 & 91,14 \\
\hline \multicolumn{3}{|c|}{ Priorytet 4. Inwestycje w innowacyjne przedsięwzięcia } \\
\hline $\begin{array}{l}\text { Działanie 4.1. Wsparcie wdrożeń wyników } \\
\text { prac B+R + }\end{array}$ & 1395,6 & 916,9 & 67,45 \\
\hline $\begin{array}{l}\text { Działanie 4.2. Stymulowanie działalności } \\
\text { B+R przedsiębiorstw oraz wsparcie } \\
\text { w zakresie wzornictwa przemysłowego }\end{array}$ & 774,1 & 687,9 & 88,89 \\
\hline $\begin{array}{l}\text { Działanie 4.4. Nowe inwestycje o wysokim } \\
\text { potencjale innowacyjnym }\end{array}$ & 7163,1 & 6517,1 & 90,98 \\
\hline \multicolumn{3}{|c|}{ Priorytet 5. Dyfuzja innowacji } \\
\hline $\begin{array}{l}\text { Działanie 5.2. Wspieranie instytucji otoczenia } \\
\text { biznesu świadczących usługi proinnowacyjne } \\
\text { oraz ich sieci o znaczeniu ponadregionalnym }\end{array}$ & 274,6 & 257,5 & 93,75 \\
\hline
\end{tabular}




\begin{tabular}{|c|c|c|c|}
\hline Priorytet/działanie/poddziałanie & $\begin{array}{c}\text { Alokacja } \\
\text { w mln PLN }\end{array}$ & $\begin{array}{l}\text { Wykorzystanie } \\
\text { w mln PLN }\end{array}$ & $\begin{array}{l}\text { Wykorzystanie } \\
\text { alokacji w \% }\end{array}$ \\
\hline $\begin{array}{l}\text { Działanie 5.3. Wspieranie ośrodków } \\
\text { innowacyjności }\end{array}$ & 1033,3 & 1073,2 & 103,86 \\
\hline $\begin{array}{l}\text { Działanie 5.4. Zarządzanie własnością } \\
\text { intelektualną }\end{array}$ & 106,7 & 55,5 & 52,94 \\
\hline \multicolumn{4}{|c|}{ Priorytet 6. Polska gospodarka na rynku międzynarodowym } \\
\hline Działanie 6.1. Paszport do eksportu & 344,2 & 326,8 & 94,94 \\
\hline \multicolumn{4}{|c|}{ Priorytet 8. Społeczeństwo informacyjne } \\
\hline $\begin{array}{l}\text { Działanie 8.1. Wspieranie działalności } \\
\text { gospodarczej w dziedzinie gospodarki } \\
\text { elektronicznej }\end{array}$ & 1306,4 & 1223,3 & 93,64 \\
\hline $\begin{array}{l}\text { Działanie 8.2. Wspieranie wdrażania } \\
\text { elektronicznego biznesu typu B2B } \\
\text { (szczególnie MSP) }\end{array}$ & 1630,9 & 1612,7 & 98,88 \\
\hline $\begin{array}{l}\text { Działanie 8.4. Zapewnienie dostępu do } \\
\text { Internetu na etapie „ostatniej mili” (MSP) }\end{array}$ & 797,5 & 604,4 & 75,79 \\
\hline \multicolumn{4}{|c|}{ Program operacyjny Rozwój Polski Wschodniej (PO RPW) } \\
\hline \multicolumn{4}{|c|}{ Priorytet 1. Nowoczesna gospodarka } \\
\hline Działanie 1.3. Wspieranie innowacji & 2012,8 & 1926,8 & 95,73 \\
\hline \multicolumn{4}{|c|}{ Priorytet 2. Infrastruktura społeczeństwa informacyjnego } \\
\hline $\begin{array}{l}\text { Działanie 2. Sieć szerokopasmowa Polski } \\
\text { Wschodniej }\end{array}$ & 1207,8 & 778,6 & 64,46 \\
\hline \multicolumn{4}{|c|}{ Priorytet 3. Wojewódzkie ośrodki wzrostu } \\
\hline $\begin{array}{l}\text { Działanie 3.2. Infrastruktura turystyki } \\
\text { kongresowej i targowej }\end{array}$ & 248,2 & 224,4 & 90,41 \\
\hline \multicolumn{4}{|c|}{ Priorytet 5. Zrównoważony rozwój potencjału turystycznego opartego o warunki naturalne } \\
\hline $\begin{array}{l}\text { Działanie 5.1. Promowanie zrównoważonego } \\
\text { rozwoju turystyki }\end{array}$ & 19,2 & 19,2 & 100 \\
\hline \multicolumn{4}{|c|}{ Program Operacyjny Kapitał Ludzki (PO KL) } \\
\hline \multicolumn{4}{|c|}{$\begin{array}{c}\text { Priorytet 2. Rozwój zasobów ludzkich i potencjału adaptacyjnego przedsiębiorstw } \\
\text { oraz poprawa stanu zdrowia pracujących }\end{array}$} \\
\hline $\begin{array}{l}\text { Poddziałanie 2.1.1. Rozwój kapitału } \\
\text { ludzkiego w przedsiębiorstwach }\end{array}$ & 1651,1 & 1513,6 & 91,67 \\
\hline $\begin{array}{l}\text { Poddziałanie 2.2.1. Poprawa jakości usług } \\
\text { świadczonych przez instytucje wspierające } \\
\text { rozwój przedsiębiorczości i innowacyjności }\end{array}$ & 274,2 & 227,2 & 82,86 \\
\hline \multicolumn{4}{|c|}{ Priorytet 8. Regionalne kadry gospodarki } \\
\hline $\begin{array}{l}\text { Poddziałanie 8.1.1. Wspieranie rozwoju } \\
\text { kwalifikacji zawodowych i doradztwo dla } \\
\text { przedsiębiorstw }\end{array}$ & 4196,9 & 4000,3 & 95,32 \\
\hline $\begin{array}{l}\text { Poddziałanie 8.1.2. Wsparcie procesów } \\
\text { adaptacyjnych i modernizacyjnych w regionie }\end{array}$ & 1486,9 & 1386,2 & 93,23 \\
\hline
\end{tabular}

Źródło: opracowanie własne na podstawie sprawozdań końcowych z PO IG, PO RPW i PO KL. 
kroczyła 90\% alokacji. Biorąc pod uwagę obszary wsparcia o najwyższym dofinansowaniu, należy zwrócić uwagę przede wszystkim na Działanie 4.4. Nowe inwestycje o wysokim potencjale innowacyjnym. W jego zakresie przedsiębiorcy zrealizowali projekty inwestycyjne, których głównym celem było podniesienie poziomu innowacji, co ma kluczowe znaczenie dla konkurencyjności naszych regionów. Ze wszystkich wymienionych w tabeli 6 programów operacyjnych przedsiębiorcy skorzystali przede wszystkim z Programu Operacyjnego Innowacyjna Gospodarka. To w PO IG, mikro-, małe i średnie przedsiębiorstwa stanowią największy odsetek beneficjentów zarówno pod względem ilości, jak i wysokości otrzymanych dotacji. Łącznie w całym programie zawarto ok. 18,5 tys. umów, z tego prawie $85 \%$ zrealizowali przedsiębiorcy (MIiR, 2015).

Program Operacyjny Kapitał Ludzki stanowi kontynuację SPO Rozwój Zasobów Ludzkich. W ramach PO KL przedsiębiorcy mogli brać udział w różnych formach podnoszenia kwalifikacji, doszkalania swoich pracowników oraz korzystania z doradztwa finansowego i gospodarczego. W ramach tego programu istniała też możliwość, dzięki Działaniu 6.2. Wsparcie oraz promocja przedsiębiorczości i samozatrudnienia, założenia własnej działalności gospodarczej. Celem Działania była promocja oraz wspieranie inicjatyw i rozwiązań zmierzających do tworzenia nowych miejsc pracy oraz budowy postaw kreatywnych, służących rozwojowi przedsiębiorczości i samozatrudnienia. Beneficjenci tego Działania otrzymywali wsparcie szkoleniowe, doradcze $\mathrm{i}$ finansowe $\mathrm{w}$ formie wsparcia pomostowego i jednorazowej dotacji inwestycyjnej do 40 tys. PLN. Efektem tego Działania było powstanie ok. 1000 mikroprzedsiębiorstw do końca 2013 r. (MIiR, 2015).

Dużą zmianą dla przedsiębiorców (w stosunku do poprzedniego okresu programowania) było zastąpienie Zintegrowanego Programu Operacyjnego Rozwoju Regionalnego (zarządzanego centralnie, a realizowanego regionalnie) 16 Regionalnymi Programami Operacyjnymi, które z założenia miały być bardziej dostosowane do potrzeb poszczególnych województw. Tworzone były „oddolnie”, czyli gmina budowała swój plan rozwoju, przekazywała na poziom powiatu, powiat zaś - na poziom województwa do Urzędu Marszałkow- skiego, który odpowiadał za jego realizację. Analizując SWOT dla naszych regionów (województw), możemy zwrócić uwagę, że prawie wszystkie regiony zidentyfikowały zbyt niski poziom konkurencyjności sektora MSP, przede wszystkim z perspektywy jego innowacyjności oraz niskiego poziomu kapitału własnego. $\mathrm{Z}$ tego też względu w każdym z 16 RPO znajdziemy działania wspierające rozwój firm przez inwestycje w nowoczesne technologie oraz kapitał ludzki. Przyjęta zasada programowania RPO (czyli powstanie w rzeczywistości 16 różnych Programów Operacyjnych) spowodowała zróżnicowanie przedsiębiorców w dostępie do środków unijnych. To zarząd regionu decydował ile $\mathrm{z}$ całej wynegocjowanej kwoty na RPO przeznaczy dla sektora MSP. Rozbieżność była duża, np. w województwie opolskim udział wyniósł ok. $50 \%$, w małopolskim - ok. 20\%, a w mazowieckim - ok. 30\%. Oczywiście przyjęte poziomy dofinansowania sektora MSP w ramach RPO zdywersyfikowały zarówno ilość, jak i wielkość otrzymanego wsparcia.

Reasumując drugi okres programowania pod kątem funkcjonowania sektora MSP, zrealizowane inwestycje przyczyniły się do podniesienia konkurencyjności, zwłaszcza z perspektywy działań innowacyjnych, umożliwiły współpracę $\mathrm{z}$ instytucjami naukowo-badawczymi oraz wpłynęły na jakość kapitału ludzkiego tak zarządzającego, jak i pracującego w mikro-, małych i średnich firmach.

\subsubsection{Trzeci okres programowania 2014-2020}

Kolejny okres programowania na lata 2014-2020 to dla Polski możliwość wykorzystania alokacji na poziomie ok. 82,5 mln euro. Podobnie jak w latach 2007-2013, jesteśmy największym biorcą netto $\mathrm{z}$ funduszy unijnych. Wynegocjowana pula środków zostanie przeznaczona na wsparcie działań innowacyjnych, rozwój przedsiębiorczości, budowę infrastruktury drogowej, badania i rozwój oraz rozwój społeczeństwa informacyjnego.

W obecnym okresie programowania cele oraz zasady wykorzystania funduszy unijnych zostały zawarte w ramach Umowy Partnerstwa ${ }^{10}$. W nowym okresie programowania beneficjenci będą mieli do dyspozycji 7 Programów Operacyjnych. Ich poziom alokacji prezentuje rysunek 1 . 
Rysunek 1. Wartość alokacji na poszczególne Programy Operacyjne w mld euro

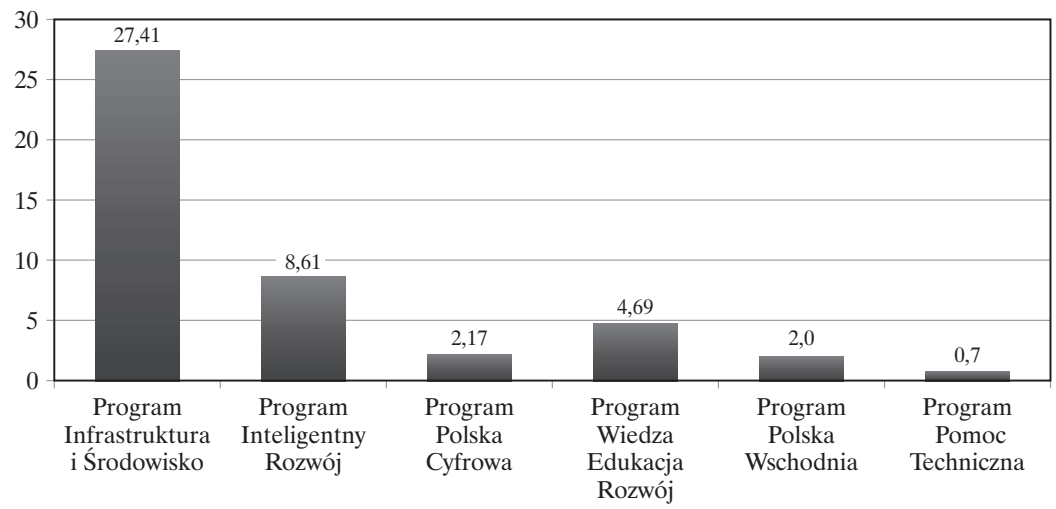

Źródło: opracowanie własne na podstawie Umowy Partnerstwa.

Analiza danych z rysunku 1 potwierdza tendencje, które zostały zaprezentowane w Umowie Partnerstwa w zakresie realizacji inwestycji dotowanych z funduszy unijnych. Ponad połowę $-79,03 \%$ stanowi plan inwestycyjny związany $\mathrm{z}$ rozwojem infrastruktury i środowiska oraz działaniami zaplanowanymi $\mathrm{w}$ ramach inteligentnego rozwoju. Wartościowo na te dwa programy przeznaczono kwotę ok. 36 mld euro.

Konstrukcja Programów Operacyjnych na lata 2014-2020 rożni się od poprzedniego okresu programowania, gdyż priorytety zostały dostosowane do tzw. celów tematycznych ${ }^{11}$. Środki przeznaczone dla sektora MSP mają obecnie wspierać konkurencyjność gospodarki głównie przez innowacje tworzone we współpracy sektora biznesu ze światem nauki (Krasuska, 2014). Wybrane Programy Operacyjne dla przedsiębiorców, cele oraz osie priorytetowe prezentuje tabela 6 .

Największa zmiana w stosunku do poprzedniego okresu programowania 2007-2013 wiąże się z Programem Operacyjnym Polska Wschodnia. W przeciwieństwie do Programu Operacyjnego Rozwój Polski Wschodniej to przede wszystkim firmy, a nie szkoły i samorządy, będą głównym odbiorcą zaplanowanej pomocy. Do beneficjentów trafi kwota ok. 960 mln euro. Start-upy, internacjonalizacja sektora MSP oraz promocja międzynarodowa to główne kierunki zakładanych inwestycji.

Podobnie jak w latach 2007-2013, obsługa przedsiębiorców została zaplanowana w ramach Regionalnych Programów Operacyjnych i będzie obsługiwana na poziomie urzedów marszałkowskich. Zakłada się wspólfinansowanie m.in. takich projektów, jak: handel elektroniczny, tworzenie nowych miejsc pracy oraz inwestycje $\mathrm{w}$ innowacyjne przedsięwzięcia.

Kolejną „nowością” związaną z kreowaniem postaw przedsiębiorczych są pożyczki udzielane w ramach PO WER na rozpoczęcie własnej działalności gospodarczej. Ta forma wsparcia kierowana jest do ludzi młodych do 29 r.ż. Środkami na ten cel zarządza Bank Gospodarstwa Krajowego.

Ocenę przyjętych zasad programowania oraz trafności doboru działań w osiach priorytetowych będziemy mogli częściowo ocenić już na koniec 2017 r., gdyż wtedy nastąpi przegląd okresowy zrealizowanych form wsparcia w ramach wszystkich 7 Programów Operacyjnych.

Zagadnieniem niezwykle istotnym z perspektywy efektywności absorpcji funduszy unijnych są ograniczenia w pozyskaniu tej formy dofinansowania. Biorąc pod uwagę m.in. raporty dotyczące zamknięcia programów operacyjnych, takie jak: Wptyw realizacji sektorowego programu operacyjnego WKP na lata 2004-2006 na poziom innowacyjności polskich przedsiębiorstw. Raport końcowy. Uniconsult, Warszawa 2008; Stan wykorzystania funduszy europejskich. BCC, Warszawa 2014 oraz Końcowy raport z postepu wdrażania Zintegrowanego Programu Operacyjnego Rozwoju Regionalnego 2004-2006, Warszawa 2010, jak też opinię badaczy (Wolański, Piotrowski, Cieślak, Janasz, Heller) oraz stanowisko osób bezpośrednio zarządzających projektami (w tym autora niniejszego opracowa- 
Tabela 6. Wybrane Programy Operacyjne i priorytety dla przedsiębiorców na lata 2014-220

\begin{tabular}{|c|c|c|}
\hline Nazwa Programu & Cel & Oś priorytetowa \\
\hline \multirow{3}{*}{$\begin{array}{l}\text { Program Operacyjny } \\
\text { Inteligentny Rozwój }\end{array}$} & \multirow{3}{*}{$\begin{array}{l}\text { Wzrost innowacyjności polskiej } \\
\text { gospodarki } \\
\text { realizacja celu zostanie zapewniona } \\
\text { przez zwiększenie nakładów } \\
\text { przedsiębiorców na B+R, warunkiem } \\
\text { rozliczenia projektów będzie ich } \\
\text { wdrożenie }\end{array}$} & $\begin{array}{l}\text { I. Wsparcie prowadzenia prac } \\
\mathrm{B}+\mathrm{R} \text { przez przedsiębiorstwa }\end{array}$ \\
\hline & & $\begin{array}{l}\text { II. Wsparcie otoczenia } \\
\text { i potencjału przedsiębiorstw } \\
\text { do prowadzenia działalności } \\
\mathrm{B}+\mathrm{R}+\mathrm{I}\end{array}$ \\
\hline & & $\begin{array}{l}\text { III. Wsparcie innowacji } \\
\text { w przedsiębiorstwach }\end{array}$ \\
\hline $\begin{array}{l}\text { Program Operacyjny } \\
\text { Wiedza Edukacja } \\
\text { Rozwój }\end{array}$ & $\begin{array}{l}\text { dla programu POWER nie ma } \\
\text { jednego celu głównego; cele zostały } \\
\text { dopasowane do osi priorytetowych; } \\
\text { do najważniejszych zaliczamy m.in.: } \\
\text { podniesienie kompetencji osób } \\
\text { uczestniczących w procesie edukacji, } \\
\text { zwiększenie zatrudnienia osób młodych } \\
\text { do } 29 \text { r.ż., zwiększenie efektywności } \\
\text { funkcjonowania urzędów publicznych } \\
\text { na rynku pracy, profesjonalizację kadr } \\
\text { instytucji rynku pracy, zapewnienie } \\
\text { wysokiej jakości usług świadczonych na } \\
\text { rzecz przedsiębiorców oraz zwiększenie } \\
\text { mobilności ponadnarodowej }\end{array}$ & $\begin{array}{l}\text { II. Efektywne polityki } \\
\text { publiczne dla rynku pracy, } \\
\text { gospodarki i edukacji }\end{array}$ \\
\hline $\begin{array}{l}\text { Program Operacyjny } \\
\text { Polska Wschodnia }\end{array}$ & $\begin{array}{l}\text { Wzrost konkurencyjności } \\
\text { i innowacyjności makroregionu Polski } \\
\text { Wschodniej } \\
\text { cel zostanie osiągnięty m.in. przez } \\
\text { tworzenie warunków sprzyjających } \\
\text { powstawaniu innowacyjnych MŚP } \\
\text { w Polsce Wschodniej oraz budowę } \\
\text { nowych modeli biznesowych w celu } \\
\text { umiędzynarodowienia działalności MŚP }\end{array}$ & $\begin{array}{l}\text { I. Przedsiębiorcza Polska } \\
\text { Wschodnia }\end{array}$ \\
\hline
\end{tabular}

Źródło: opracowanie własne na podstawie dokumentów programowych do PO IR, PO WER i PO PW.

nia), do najczęściej wskazywanych barier możemy zaliczyć m.in.:

1) konieczność przygotowania projektu w zbyt rozbudowanych generatorach wniosków o dofinansowanie, co powoduje niejednokrotnie konieczność skorzystania $\mathrm{z}$ dodatkowo płatnych usług firm consultingowych;

2) preferowanie w ogłaszanych konkursach firm produkcyjnych, co może zakłócać zasadę konkurencyjności w dostępie do tej formy finansowania;

3) brak - zwłaszcza przez firmy typu start-up - środków finansowych na wkład własny;

4) zbyt długi czas oczekiwania na decyzję o przyznaniu środków (niejednokrotnie powyżej 6 m-cy od daty złożenia wniosku o dofinansowanie);

5) zbyt niski poziom tzw. zaliczki (maksymalnie $20 \%$ wartości dofinansowania);

6) zbyt rozbieżne (pomiedzy regionami) interpretacje przepisów wdrożeniowych;

7) duże rozdrobnienie programów, które powoduje problemy w dostępie do informacji dotyczących zasad ogłaszanych konkursów;

8) brak uproszczeń związanych z ubieganiem się o fundusze unijne dla mikroprzedsiębiorców w zakresie realizacji małych projektów, co powoduje ograniczenie wykorzystania wsparcia unijnego przez ten sektor gospodarki; 
9) zbyt rozbudowane i długie procedury rozliczenia projektów, które mogą spowodować utratę płynności finansowej.

Podsumowując, każdy okres programowania inkubował różne bariery w dostępie do funduszy unijnych. Musimy jednak pamiętać o głównym atrybucie tej formy interwencji finansowej, który wpływa bezpośrednio na ich atrakcyjność w procesie inwestycyjnym, czyli bezzwrotną formę dofinansowania.

\section{Wyniki badań}

Analizując zrealizowane formy wsparcia z funduszy unijnych dla sektora MSP, autor niniejszego artykułu przeprowadził w 2014 roku badanie ankietowe, w ramach którego respondenci wypowiedzieli się m.in. na temat: czy inwestycja w rozwój firmy mogłaby zostać zrealizowana $\mathrm{z}$ innych środków niż fundusze unijne, a jeżeli nie to dlaczego? Zdaniem autora, beneficjenci dotacji unijnych wysoko oceniają tę formę interwencji finansowej jako jednej z głównych determinantów rozwoju przedsiębiorczości, jak też uzależniają podjęcie decyzji inwestycyjnej od otrzymania dotacji z funduszy unijnych.

Badanie zostało przeprowadzone na 277 respondentach prowadzących działalność gospodarczą lub pracujących w różnych instytucjach publicznych, biorących udział w projektach (jako ich beneficjenci) bądź też realizujących projekty w drugim okresie programowania, tj. w latach 20072013. Pod względem podziału na płeć rozkład w grupie badawczej był następujący: 91 mężczyzn (33\%) i 186 kobiet $(67 \%)$.

Osoby badane miały odpowiedzieć na pytanie, czy planowana inwestycja bytaby zrealizowana ze środków innych niż UE? oraz jeżeli nie - to dlaczego? Wybierając „NIE”, beneficjent mógł wskazać: brak kapitatu wtasnego, niedostateczna informacja na temat innych źródet finansowania, zbyt duże ryzyko finansowe, każdy beneficjent mógł zaznaczyć wszystkie 3 opcje.

$\mathrm{Na}$ pierwszą część pytania, czy planowana inwestycja bytaby zrealizowana ze środków innych niz UE?, TAK odpowiedziało 55 osób, NIE - 222 osoby. Uzyskany wynik w podziale na kategorie, dlaczego nie? prezentuje tabela 7 .

Jak możemy wnioskować na podstawie wyników zaprezentowanych w tabeli 8, tylko 55 osób, tj. ok. $20 \%$, zrealizowałoby swoją inwestycję $\mathrm{z}$ innych środków niż fundusze unijne. Pozostałe (222 osoby) stwierdziły, że nie zrealizowałyby zaplanowanej inwestycji. Brak kapitału własnego wskazano 190 razy, niedostateczną informację na temat innych źródeł finansowania -82 razy i zbyt duże ryzyko finansowe - 128 razy. Możemy zatem stwierdzić, że obecnie decyzje finansowe podejmowane w momencie planowania inwestycji są bardzo uzależnione od pozyskania kapitału zewnętrznego w formie dotacji unijnych (pomimo wcześniej wskazanych głównych barier). Ryzyko finansowe i brak kapitału własnego to główne przyczyny niezrealizowania procesu inwestycyjnego.

\section{Podsumowanie}

Warunki makroekonomiczne funkcjonowania firm na rynku europejskim od 2010 roku ulegają ciągłej poprawie. Zauważalny rozwój gospodarczy oraz przyśpieszenie popytu krajowego wpływa pozytywnie na rozwój mikro-, małej i średniej przedsiębiorczości. Sektor MSP od 2004 roku,

Tabela 7. Zestawienie odpowiedzi

\begin{tabular}{|c|c|c|c|c|}
\hline \multicolumn{1}{|c|}{ Pytanie? } & & \multicolumn{3}{c|}{ NIE } \\
\cline { 3 - 5 } & TAK & $\begin{array}{c}\text { brak } \\
\text { kapitału } \\
\text { własnego }\end{array}$ & $\begin{array}{c}\text { niedostateczna } \\
\text { informacja } \\
\text { na temat } \\
\text { innych źródel } \\
\text { finansowania }\end{array}$ & $\begin{array}{c}\text { zbyt duże } \\
\text { ryzyko } \\
\text { finansowe }\end{array}$ \\
\hline $\begin{array}{l}\text { Czy planowana inwestycja byłaby } \\
\text { zrealizowana ze środków innych niz } \\
\text { UE? }\end{array}$ & 55 & 190 & 82 & 128 \\
\hline
\end{tabular}

Źródło: opracowanie własne. 
czyli od momentu akcesji Polski do UE, ma możliwość czynnego udziału w budowie rynku europejskiego. Jak już zostało w niniejszym artykule wspomniane, przedsiebiorstwa tworza ok. $73 \% \mathrm{PKB}, \mathrm{z}$ czego MSP generują prawie $49 \%$ i inkubują ok. $62 \%$ miejsc pracy. Dobra kondycja sektora MSP przekłada się bezpośrednio na wszystkie wskaźniki rozwoju regionalnego, począwszy od PKB per capita, a na stopie bezrobocia kończac. $\mathrm{Z}$ tego też względu bardzo ważną rolę w podnoszeniu konkurencyjności regionu odgrywa odpowiednie programowanie procesu wsparcia MSP oraz jego internacjonalizacja, która w ostatnim okresie programowania odnotowuje tendencję wzrostową, gdyż prawie $8 \%$ firm z sektora MSP planuje rozpoczęcie działalności międzynarodowej (PARP, 2015).

Warto też zauważyć, że z perspektywy oddziaływania funduszy unijnych na rozwój tego sektora przedsiębiorcy najczęściej skorzystali z bezzwrotnych dotacji na inwestycje, promocje ponadregionalną, rozwój kapitału ludzkiego oraz rozwój działalności innowacyjnej. Zarówno w pierwszym, jak i w drugim okresie programowania wykorzystanie funduszy dla rozwoju sektora MSP osiągnęło poziom bliski $100 \%$. W stosunku do nowych zasad programowania na lata 2014-2020 możemy zastanowić się, jak przedsiębiorcy będą nadal wykorzystywać te forme interwencji finansowej, biorac pod uwagę, że w nowym okresie przewiduje się zastąpienie części dotacji, które miały formę bezzwrotną, pożyczkami, np. na założenie nowego mikroprzedsiębiorstwa.

Istotną cechą współfinansowania unijnego jest po pierwsze, konieczność poniesienia całości kosztów inwestycji z kapitału własnego (jedna z barier), które dopiero po rozliczeniu projektu są zwracane inwestorowi (Czternasty i Mikołajczak, 2010). Dopiero zaś od drugiego okresu programowania (2007-2013) funkcjonuje forma zaliczki, która powinna być jednak uzależniona od „kondycji ekonomicznej” regionu, a nie wystandaryzowana dla całości kraju. Po drugie, adresowane są do różnego typu beneficjenta na różnorodne cele (np.: poprawa jakości życia czy też rozwój najbiedniejszych regionów) związane bezpośrednio z rozwojem społeczno-gospodarczym Polski.

Reasumując, można stwierdzić jednoznacznie (zgodnie m.in. z R. Wolańskim i P. Mikołajczakiem), że fundusze Unii
Europejskiej były i nadal są determinantami rozwoju sektora MSP, dzięki któremu $\mathrm{z}$ roku na rok nasza gospodarka podnosi swoją konkurencyjność i innowacyjność, stając się „ważnym graczem” globalnego rynku europejskiego.

\section{Przypisy}

1 Należą do nich: zakładanie firmy, czyli procedury, czas oraz wymagany minimalny wkład początkowy; uzyskiwanie pozwoleń na budowę, czyli procedury, czas oraz koszt inspekcji oraz uzyskiwania pozwolenia; wskaźnik energii elektrycznej, czyli czas i koszt uzyskania przylącza elektrycznego dla nowo wybudowanego przedsiębiorstwa; rejestrowanie własności, czyli procedury, czas oraz koszt rejestrowania nieruchomości; otrzymywanie kredytu, czyli stopień regulacji kredytów oraz ilość informacji na temat kredytowania; ochrona inwestorów, czyli zakres jawności oraz zakres odpowiedzialności zarządu przed współudziałowcami; płacenie podatków, czyli liczba płaconych podatków, godziny speedzone rocznie nad przygotowaniem zeznań podatkowych oraz cześć dochodu brutto, jaką stanowi płacony podatek; handel zagraniczny, czyli liczba dokumentów, podpisów i czasu wymaganego, aby przedsiębiorca mógł importować lub eksportować; zawieranie umów, czyli procedury, czas i koszt zawierania i egzekwowania umów dłużnych; likwidacja przedsiębiorstwa, czyli czas i koszt związany z zakończeniem działalności oraz stopa odzysku, regulacje rynku pracy (wskaźnik dodany w 2016 r.), czyli elastyczność w zatrudnianiu oraz jakość miejsca pracy.

2 Cel ten jest taki sam dla obu polityk i praktycznie polega na wspieraniu działań prowadzacych do wyrównania warunków ekonomicznych i społecznych we wszystkich regionach Unii Europejskiej.

3 Więcej na temat polityki regionalnej i jej instrumentów w: Dubel, 2012.

4 Obecnie w Polsce mamy 15 regionów nierozwiniętych i jeden region w fazie przejściowej (woj. mazowieckie).

5 Europejski Fundusz Społeczny (EFS) - powstał w 1957 roku. Współfinansuje on działania krajów członkowskich w dziedzinie polityki zatrudnienia i rozwoju zasobów ludzkich (twz. projekty miękkie).

6 Europejski Fundusz Rozwoju Regionalnego (EFRR) - został utworzony w 1975 roku. Celem EFRR jest zwiększenie spójności gospodarczej i społecznej w Unii Europejskiej oraz zlikwidowanie nierówności pomię̨zy regionami. EFRR finansuje $\mathrm{m}$. in. bezpośrednie wsparcie inwestycji realizowanych przez sektor MSP. 
7 Dyrektywa usługowa dotyczy: uproszczenia procedur administracyjnych, wzmocnienia praw konsumentów i przedsiębiorców korzystających z usług oraz wspierania współpracy pomiędzy krajami UE.

8 W dniu 14 stycznia 2003 r. Rada Ministrów zatwierdziła NPR na lata 2004-2006, w którym zawarto analizę sytuacji społeczno-gospodarczej, określono priorytetowe potrzeby oraz cele, do których zaliczamy m.in.: wspieranie konkurencyjności przedsiębiorstw, rozwój zasobów ludzkich i zatrudnienia oraz promowanie zrównoważonego rozwoju.

9 NSRO prezentuje strategię rozwoju społeczno-gospodarczego kraju, w tym cele polityki spójności w Polsce w latach 2007-2013 oraz określa system wdrażania funduszy unijnych. Dokumen został zaakceptowany przez KE 9 maja 2007 r.

10 Umowa Partnerstwa to główny dokument na poziomie krajowym. W dokumencie wskazano m.in. rodzaje inwestycji, które będą mogły liczyć na dofinansowanie, zaproponowano układ programów operacyjnych i systemu ich wdrażania.

11 Cele tematyczne to obszary wyznaczone przez UE, w których realizowane inwestycje moga być spółfinansowane $\mathrm{z}$ funduszy unijnych. Na lata 20014-2020 mamy 11 celów tematycznych. Jednym z celów - Celem 3 jest podniesienie konkurencyjności sektora MSP.

\section{Bibliografia}

Bachtler, J. (1996). Longer Term Perspectives on Regional Policy in Europe. Glasgow.

Burnat-Mikosz, M., Gwiazda, M. i Kosewska-Kwaśny, M. (2007). Programy pomocowe oraz dotacje UE dla przedsiębiorców 2007-2013. Warszawa: C.H Beck.

Cieślak, A. (2008). Firmom trudniej zdobyć dotacje. Rzeczpospolita $n r$ 44. 02.2008

Czternasty, W., Mikołajczak, P. (2010). Rozwój małych i średnich przedsiębiorstw w Polsce a źródła ich finansowania. Współczesne dylematy. W: Nowe trendy $w$ metodologii nauk ekonomicznych (t. 1). Poznań: Uniwersytet Ekonomiczny

Dubel, P. (2012). Polityka regionalna i fundusze strukturalne $w$ praktyce. Warszawa: Wydawnictwo Naukowe WZ UW.

Heller, J. (2010). Fundusze europejskie w kształtowaniu rozwoju gospodarczego województw w Polsce. Samorzad terytorialny $n r 7-8$.

Hryniewicka, M. (2015). Wptyw funduszy unijnych na rozwój sektora MSP w Polsce w latach 2007-2013. Warszawa: Difin.

Janasz, K. (2010). Kapitat $w$ finansowaniu dziatalności innowacyjnej przedsiębiorstw w Polsce. Źródta $i$ modele. Warszawa: Difin.
Krasuska, M. (2014). Fundusze unijne $w$ nowej perspektywie 2014-2020. Warszawa: Wiedza i Praktyka sp. z o.o.

Kuzek, D. (2011). Bariery rozwoju małych i średnich przedsiębiorstw w Polsce. W: Studies \& Proceedings of Polish Association for Knowledge Management. Nr 57. Bydgoszcz: Polskie Stowarzyszenie Zarządzania Wiedza.

Kwieciński, J., Kalamon, B. (2014). Stan wykorzystania funduszy europejskich - VIII raport. Warszawa: BCC.

Levison, M. (1992). Nie tylko wolny rynek, odrodzenie aktywnej polityki gospodarczej. Warszawa: PWE.

Mikołajczak, P. (2012). Wptyw funduszy Unii Europejskiej na zmiany $w$ sposobie dziatania matych $i$ średnich przedsiebiorstw $w$ Wielkopolsce. W: Ekonomia 4(21). Wrocław: Wydawnictwo Uniwersytetu Ekonomicznego.

MG. (2003). Narodowy Plan Rozwoju. Warszawa: Ministerstwo Gospodarki, Pracy i Polityki Społecznej.

MIiR. (2014). Programowanie perspektywy finansowej - Umowa Partnerstwa. Warszawa: Ministerstwo Infratruktury i Rozwoju.

MIiR. (2015). Sprawozdanie okresowe z realizacji PO IG. Warszawa: Ministerstwo Infratruktury i Rozwoju.

MIiR. (2015a). Sprawozdanie z realizacji PO KL. Warszawa: Ministerstwo Infratruktury i Rozwoju.

MIiR. (2014). Program Operacyjny Wiedza Edukacja Rozwój. Warszawa: Ministerstwo Infratruktury i Rozwoju.

MIiR. (2014). Program Operacyjny Inteligentny Rozwój. Warszawa: Ministerstwo Infratruktury i Rozwoju.

MIiR. (2014). Program Operacyjny Polska Wschodnia. Warszawa: Ministerstwo Infratruktury i Rozwoju.

MRR. (2007). Narodowe Strategiczne Ramy Odniesienia. Warszawa: Ministerstwo Rozwoju Regionalnego.

MRR. (2010). Końcowy raport z postępu wdrażania ZPORR. Warszawa: Ministerstwo Rozwoju Regionalnego.

MRR. (2009). Końcowy raport z wdrażania SPO WKP. Warszawa: Ministerstwo Rozwoju Regionalnego.

Oliński, M. (2006). Pomoc publiczna a rozwój małych i średnich przedsiębiorstw. W: B. Kożuch, Problemy zarzadzania organizacjami publicznymi. Kraków: Uniwersytet Jagielloński.

Piotrowski, Sz. (2009). Konkurencyjność a uwarunkowania prawne polityki konkurencji UE. W: M. Gorynia., Łaźniewska E., Kompendium wiedzy o konkurencyjności. Warszawa: PWN. 
PARP. (2015). Raport o stanie sektora małych i średnich przedsiębiorstw w Polsce w latach 2013-2014.

Warszawa: Polska Agencja Rozwoju Przedsiębiorczości.

Pawlicki, R. (2014). Strategia finansowa dla Polski 2014-2020. Fundusze unijne dla przedsiębiorczych. Warszawa: Difin.

Rapkiewicz, M., Fijałkowski, K. (2016). Pozycja Polski w rankingu Doing Business. Kierunek zmian $w$ wybranych obszarach prowadzenia dziatalności gospodarczej. Warszawa: Instytut Sobieskiego.

Rozporządzenie Parlamentu Europejskiego i Rady (UE) $\mathrm{Nr}$ 1287/2013 z dnia 11 grudnia 2013 roku ustanawiające program na rzecz konkurencyjności przedsiebiorstw oraz małych i średnich przedsie biorstw (COSME) (2014-2020), Dz. Urz. UE L 347 $\mathrm{z}$ dnia 20 grudnia 2013 roku.
Sasin, K. (2003). Zarzadzanie mata firma. Wrocław: Akademia Ekonomiczna.

Wolański, R. (2013). Wptyw otoczenia finansowego na konkurencyjność matych i średnich przedsiębiorstw. Warszawa: Wolters Kluwer business.

World Bank Group. (2016). Doing business 2016. Measuring Regulatory Quality and Efficiency. Washington DC: World Bank.

\section{Źródła internetowe:}

www.gus.gov.pl

www. ec.europa.eu/Eurostat

www.rp.pl

www.mr.gov.pl

www.nbp.p 